
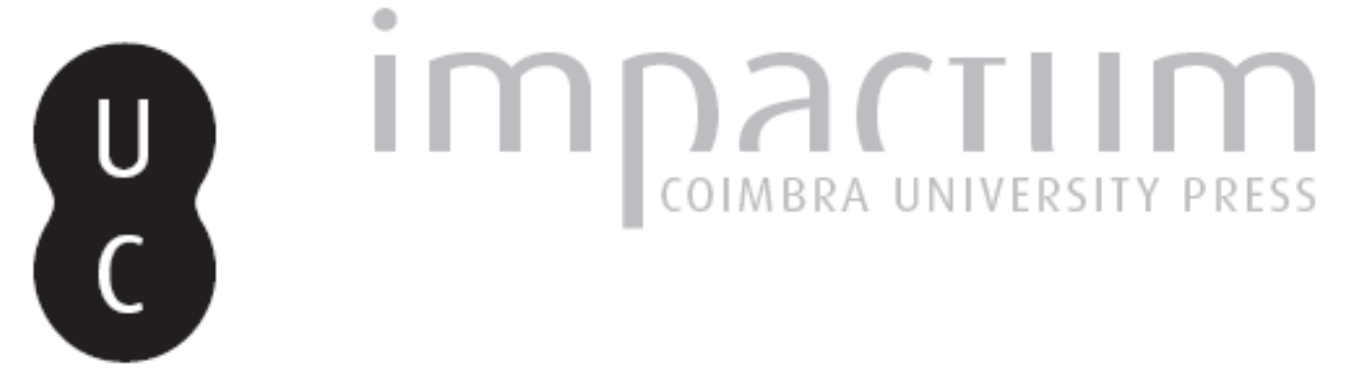

Presenças do Estoicismo no curso aristotélico jesuíta conimbricense (15921606)

Autor(es): $\quad$ Camps, Maria da Conceição; Carvalho, Mário Santiago de

Publicado por: Faculdade de Letras da Universidade de Coimbra, Instituto de Estudos

URL

persistente: URI:http://hdl.handle.net/10316.2/35583

DOI: $\quad$ DOI:http://dx.doi.org/10.14195/0872-0851_46_5

Accessed : $\quad$ 26-Apr-2023 11:09:28

A navegação consulta e descarregamento dos títulos inseridos nas Bibliotecas Digitais UC Digitalis, UC Pombalina e UC Impactum, pressupõem a aceitação plena e sem reservas dos Termos e Condições de Uso destas Bibliotecas Digitais, disponíveis em https://digitalis.uc.pt/pt-pt/termos.

Conforme exposto nos referidos Termos e Condições de Uso, o descarregamento de títulos de acesso restrito requer uma licença válida de autorização devendo o utilizador aceder ao(s) documento(s) a partir de um endereço de IP da instituição detentora da supramencionada licença.

Ao utilizador é apenas permitido o descarregamento para uso pessoal, pelo que o emprego do(s) título(s) descarregado(s) para outro fim, designadamente comercial, carece de autorização do respetivo autor ou editor da obra.

Na medida em que todas as obras da UC Digitalis se encontram protegidas pelo Código do Direito de Autor e Direitos Conexos e demais legislação aplicável, toda a cópia, parcial ou total, deste documento, nos casos em que é legalmente admitida, deverá conter ou fazer-se acompanhar por este aviso.

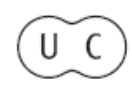




\section{REVISTA FILOSÓFICA DE COIMBRA}

vol. 23 - número 46 - outubro 2014

vol. 23 - número 46 - outubro 2014

Fundação Eng. António de Almeida

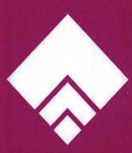




\title{
PRESENÇAS DO ESTOICISMO NO CURSO ARISTOTÉLICO JESUÍTA CONIMBRICENSE (1592-1606)
}

\author{
MARIA DA CONCEIÇÃO CAMPS \\ MÁRIO SANTIAGO DE CARVALHO*
}

\begin{abstract}
Resumo: $\mathrm{O}$ artigo representa uma primeira ou inédita sondagem às presenças ou marcas do estoicismo no Curso Aristotélico Jesuíta Conimbricense (CAJC: 1592-1606), indagando-as, primeiro, na definição ou caracterização da filosofia (§ 1); depois, nalgumas presenças genéricas mais evidentes (§ 2); de seguida, na teoria da visão (§ 3); finalmente, na moral (§ 4).
\end{abstract}

Palavras-chave: Estoicismo, aristotelismo, filosofia do século XVI, visão, ética.

Abstract: The paper is a first attempt to scrutinise the presence or signs of Stoic philosophy in the Aristotelian Jesuit Coimbra Course (CAJC: 1592-1606) by, firstly, studying the definition and characterization of 'philosophy' (§ 1); secondly, a few and broad Stoic signs ( $(2)$; then the theory of vision ( 3 ); and lastly, in morals (§ 4).

Keywords: Stoicism, Aristotelianism, 16th. Century Philosophy, Vision, Ethics.

$\S 1$. Não deixa de ser surpreendente, para um leitor desprevenido, que as primeiras linhas publicadas do Curso Aristotélico Jesuíta Conimbricense (CAJC) - sublinhemos bem: aristotélico - sejam explicitamente platónicas, ou melhor ainda, remetam para o jubilatório Protágoras de Platão. É cla-

* Maria da Conceição Camps, doutora em Filosofia e investigadora da U.I\&D, LIF (Coimbra), é responsável pela redação do $§ 3$ do presente artigo (camps.maria@gmail.com); M. S. de Carvalho, professor de Filosofia no Departamento de Filosofia, Comunicação e Informação (FLUC), e também membro da LIF, assina os restantes $\S$ (mscarvalho@fl.uc.pt). 
ro que se tratava aí designadamente de ler que a sabedoria (phrónesis) e a ciência (epistéme) são as maiores possibilidades humanas ${ }^{1}$, mas não deixa de ser singular o facto de, ainda na página de abertura do Curso, a segunda definição de filosofia, feita a partir de João Damasceno, de Séneca e de Cícero, ser estóica, "a filosofia é a ciência e o conhecimento das coisas divinas e humanas" ". Em rigor, o comentador Manuel de Góis reconhece explicitamente tratar-se de uma definição recolhida quer no Pórtico quer em Platão, "sive in Zenonis Porticu sive in Platonis Academia", e esta aproximação entre as escolas platónica e estóica é igualmente bem acolhida por Sebastião do Couto, apesar do alegado "grave dissídio" que lhes assaca, a saber: a versatilidade dialética do platonismo e a inflexibilidade dogmática do estoicismo ${ }^{3}$. Ora, uma tal aproximação entre as duas escolas derivaria de uma afirmação recorrente em S. Agostinho, e que este terá haurido em Cícero (de finibus), de acordo com a qual esses filósofos dissentiam mais sobre palavras do que sobre as matérias em causa ${ }^{4}$.

Seja como for, Góis reconhece o caráter demasiadamente genérico da definição acabada de reproduzir, e ao explicá-la somos informados que "por coisas divinas" se trata ou do que não é já material e se esconde nos recessos da natureza, ou da elevação ética que pode fazer do Homem o mais divinos dos mortais; relativamente às "coisas humanas", tratar-se-ia da materialidade, da corporalidade, bem como da conservação da vida e da sociedade civil. Notemos porém que os nossos jesuítas conhecem a posição materialista dos estóicos, que não podem acatar ${ }^{5}$, mas a explicação reconhece os campos da física e da ética. Ressaltando à vista que os Jesuítas de Coimbra não querem fazer história rigorosa - e como o poderiam fazer? - segundo a moda e o estilo da época, eles não parecem querer deixar os seus estudantes de aristotelismo na ignorância sobre as escolas platónica e estóica. Isto faz sentido,

${ }^{1}$ Commentarii Collegii Conimbricensis Societatis Iesu, In Octo Libros Physicorum Aristotelis Stagiritae. Prooemium (Coimbra 1592), 1; cf. Platão, Prot. 352d, mas também ibid. 309c, 330a, 343, 358c; 332sg; vd. M.S. de Carvalho, «Tentâmen de sondagem sobre a presença dos platonismos no volume do 'De Anima' do primeiro Curso Jesuíta Conimbricense» in J. A. de C. R. de Souza (coord.), Idade Média: tempo do Mundo, Tempo dos Homens, Tempo de Deus (Porto Alegre: EST Edições 2006), 389-98; Michael Lapidge, "The Stoic Inheritance", in P. Dronke (ed.), A History of Twelfth-Century Western Philosophy, Cambridge-New York: Cambridge University Press 1988), 81-112.

${ }^{2}$ Cf. Pseudo-Plutarco, De placitis phil. I prol. n. 2; Aecio, Placita I proem. 2 (apud G. Fraile, Historia de la Filosofia I (Madrid: BAC 1982), 600).

${ }^{3}$ Commentarii Collegii Conimbricensis e Societate Iesu, In universam Dialecticam Aristotelis Stagiritae Prooemium (Coimbra 1606) 3-4.

${ }^{4}$ Agostinho, Cidade de Deus IX c. 4 (trad. port. 827); ibid. XIV c. 9 (trad. p. 1261).

${ }^{5}$ Cf. Commentarii Collegii Conimbricensis Societatis Iesu, In tres libros de Anima Aristotelis Stagiritae II, c. 1, q.1, a.6 (Coimbra 1598) 43. 
desde logo se tivermos presente, por um lado, a nova vida editorial de Platão, sobretudo graças à intervenção de Marsilio Ficino, e, por outro, a vigência ou as expressões do neoestoicismo nos séculos XV e XVI, haja v.g. em vista a tradução que o camaldolense e discípulo de Emanuel Chrisolaras, Ambrósio Traversari, realizou, em 1432, do texto mais relevante para o conhecimento dos filósofos antigos, as Vidas de Diógenes Laércio, obra abundantemente citada no CAJC, e nomeadamente a secção sobre a Vida de Zenão ${ }^{6}$. Na mesma linha, Sebastião do Couto aduz informações doxográficas, estabelecendo a seguinte genealogia da escola do Pórtico:

Depois de Zenão, houve insignes estóicos, como Cleantes, entre outros, a que Cícero chama o estóico de grande linhagem; Diógenes Babilónico; Crisipo, filho de Apolónio, insigne pelo elogio da Dialética e escritor de inúmeros livros, de quem se disse ter amparado e sustentado nos seus ombros o pórtico dos estóicos; e também Panécio, que Cícero confessa imitar, nos livros dos Deveres. E depois, já no império de Nero, o filósofo Séneca, seu precetor; e Epicteto, oriundo de Hierápolis, cidade da Frígia, cuja admiração pela sua vida tão longa sobressaiu entre os demais, como relata Luciano Sírio... ${ }^{7}$

Necessitamos anda de evocar dois outros tópicos no início desta nossa exposição. O primeiro, mais do que relativo à segmentação das escolas filosóficas gregas, iónica e itálica, diz respeito ao acolhimento dado ao modelo de Clemente de Alexandria sobre a origem bárbara da filosofia. Quer dizer, posto que Deus é o verdadeiro autor das artes ou das ciências humanas e divinas, logo dadas a Adão e à sua progénie, como hebreus, caldeus, egípcios, gregos e ítalos, posteriormente espalhadas por todo o orbe, sejam e.g. os magos da Pérsia e da Assíria, os sacerdotes do Egito, os brâmanes e os gimnosofistas da Índia, os druidas da Gália, os sábios da Grécia, ou os doutores da Latinidade, a filosofia no seu todo é uma atividade una na sua origem divina, e por isso cosmopolita, isto é, ao serviço de todos os seres humanos ${ }^{8}$. Lembremos de passagem como se ficará a dever aos jesuítas a expansão do aristotelismo e da filosofia em geral para terras orientais e sul-americanas. O segundo tópico a concitar-nos nesta introdução remete-nos para o relevo da ética no sistema estóico, problema que, nos nossos jesuítas, passa pela

${ }^{6}$ Cf., em geral, sobre as re(edições) coevas, M.S. de Carvalho, "Introdução Geral", in Comentários do Colégio Conimbricense da Companhia de Jesus Sobre os Três Livros Da Alma de Aristóteles Estagirita. Tradução do original latino por Maria da Conceição Camps (Lisboa: Ed. Sílabo 2010) 21, 41.

${ }^{7}$ Dialectica, Prooemium, 4.

${ }^{8}$ Dialectica, Prooemium, 2; Clemente de Alexandria, Strom. II 14; Cf. J. Lagrée, Juste Lipse. La restauration du stoïcisme (Paris: Vrin 1994) 23-4; veja-se também L. Rossetti, Introduzione alla filosofia antica. Premesse filologiche e altri 'ferri del mestiere' (Bari: Levante Ed. 1998) 198-9. 
relação desta disciplina com a psicologia; notemos que esta última ciência é por eles considerada como que um compêndio das coisas humanas e divinas, e que o seu estudo (consideratio/contemplatio) é avaliado como não pertencente a nenhuma ciência média (entre a ciência natural e a metafísica), outrossim entre a filosofia natural (enquanto a alma se encontra unida ao corpo e no respeitante ao estudo da sua natureza e essência) e a metafísica (após a separação do corpo $)^{9}$. O que daqui se retira, citando Crisipo, embora de novo num sincretismo autoral confrangedor para os nossos critérios atuais, é o facto de Manuel de Góis justificar a anterioridade pedagógica da física sobre a moral ${ }^{10}$. Regressando ao primeiro ponto, verifica-se que a primeira divisão proposta de filosofia pelo Curso, em dialética, filosofia natural e moral, aparecendo explicitamente apoiada embora na Vida de Zenão, é considerada como consensual, por um arco de autores que se estende de Platão a São Tomás de Aquino, passando por Aristóteles, Plutarco e Santo Agostinho. Assim, repetimos, além de se fazer com que a filosofia pudesse ter a sua origem no próprio Deus, com aquela divisão ternária, fundamentava-se, ou pelo menos justificava-se, no fim de contas, a tríplice metódica que organizou de facto o Curso Jesuíta de Coimbra, tal como o conhecemos publicado: lógica, matéria em que, sabemos, estudantes e professores se demoravam tempo demais, como então se dizia; a física ou filosofia natural, a principal matéria das 3362 páginas publicadas em Coimbra e Lisboa; a moral, por fim, capítulo em que, também sabemos, a academia de Coimbra representava uma exceção letiva frente às suas congéneres europeias.

$\mathrm{Na}$ verdade, se quiséssemos precisar o lugar ou a ordem da Ética entre as ciências, mais do que em relação com a Dialética, que a precede enquanto ato de ciência e também no método demonstrativo ${ }^{11}$, a tese do Curso é a de que a ética é uma das três partes da filosofia comummente aceita ${ }^{12}$; que a ética antecede as outras duas disciplinas da filosofia moral, uma vez que visa a ação livre do ser humano, o modo como ele pode alcançar a felicidade e lhe permite cultivar os bons costumes ${ }^{13}$; que a sua necessidade se impõe pela relevância do tema da felicidade, da probidade dos costumes e sempre que a razão prescreve à vontade o que esta deve buscar ${ }^{14}$, dimensão que se en-

${ }^{9}$ De Anima I, c. 1, q. 1, a. 2, 8 .

${ }^{10}$ Commentarii Collegii Conimbricensis Societatis Iesu, In Octo Libros Physicorum Aristotelis Stagiritae. Prooemium, q. 5, a. 1 (Coimbra 1592) 37.

${ }^{11}$ Dialectica, Prooemium, q. 3, a. 2,19.

12 Physica, Prooemium, 3.

${ }^{13}$ In libros Ethicorum Aristotelis ad Nicomachum, aliquot Conimbricensis Cursus Disputationes in quibus praecipua quaedam Ethicae disciplinae capita continentur. Prooemium (Lisboa 1593), 3-4.

14 Physica, Prooemium, 3-4. 
contra quase metonimizada, entre outros, e.g. em Sócrates ${ }^{15}$; que é na ordem da doutrina que a ética vem a seguir à filosofia natural, exigindo-se, porém, para o seu estudo, uma maturidade maior do que aquela que se encontra nos jovens; sobretudo, que a sua dependência da física no que concerne ao estudo da alma é notável, pois em se tratando de uma 'medicina da alma', só o capítulo psicológico da física pode indicar quais são as faculdades da alma e o respetivo nível de felicidade de cada uma delas ${ }^{16}$. Seja como for, embora a ciência moral vise ensinar as razões para uma vida ética (honestum), para informar os costumes com probidade, e permitir que se alcance um estado de vida feliz; ou seja, apesar da sua utilidade para a sociedade humana, e mais necessária à vida, nem por isso ela é a ciência mais relevante (honorabilius $)^{17}$. Escusado será dizer que, e distintamente do que sucedia no estoicismo, aquela palma deverá ser dada à física, à metafísica e à teologia.

E no entanto, sem partilharem da tese do verdadeiro fundador do neoestoicismo, o ex-aluno dos jesuítas Justus Lipsius (1547-1606) - cujo ecletismo, defendido em Manuductio (1604), se propunha não aderir a nenhum escola, fazendo antes prevalecer Aristóteles na filosofia natural, Platão na religião, e o estoicismo como escolha acertada para quem quisesse descobrir Deus na natureza criada ${ }^{18}$ - parece-nos ser de avançar que, não obstante, e como seria natural, este último desiderato, ser, no Curso Jesuíta Conimbricense, quase preenchido por uma versão sui generis da filosofia do Perípato, sem se necessitar de confinar Platão ao capítulo da religião, ainda que o autor do Protágoras, e como deixámos dito, não fosse subestimado, a descoberta de Deus na natureza não podia deixar de ser totalmente alheia a uma ou outra ideias estóicas. Por exemplo, já há muito tempo que havíamos atentado no modo como Galeno servia uma teologia teleológica, conferindo um outro nível à relevância da causa final aristotélica. Ou dito de outra maneira, e para o que aqui nos interessa, algum acolhimento do estoicismo irá contribuir operatoriamente para uma leitura teológica da natureza. Sublinhemos, depois, alguma espontaneidade nesta transferência, desde logo porque ela havia sido há muito tempo defendida na Patrística - recordaria Tertuliano, São Basílio, João Crisóstomo, São Jerónimo, Atenágoras e as suas marcas ou testemu-

15 Physica, Prooemium, q. 1, a. 6,12; Dialectica, Prooemium, 2.

16 De Anima, Prooemium,1; Physica, Prooemium, q. 3, a.1, 25.

17 Physica, Prooemium, q. 5, a. 4, 42.

18 Cf. B.P. Copenhaver \& Ch. B- Schmitt, Renaissance Philosophy (Oxford-New York: Oxford University Press 2002) 267: "Lipsius wanted to uncover nature's God through a philosophy that bases ethics and theology on physics. Ethically and theologically, the key premises are that God's laws are nature's laws and that the good life conforms to nature. Within nature the Stoics detected a logos or principle of order which they treated as an aspect of divinity..." 
nhos em doutrinas como a da ordem, da providência, do bonum naturae da alma humana, ou do antropocentrismo cosmológico ${ }^{19}$ - ao que importa agregar a situação de contemporaneidade entre a publicação de alguma literatura patrística e o surgimento da Companhia de Jesus ${ }^{20}$.

$\S 2$. A primeira vez que se ouve falar de um autor estóico a propósito do Curso é ainda muito anterior à redação dos milhares de páginas que chegaram aos prelos de madeira em Coimbra e em Lisboa. Na sequência da atribuição a Pedro da Fonseca, por Jerónimo Nadal, da encomenda do Curso (1561), distribuindo tarefas para um trabalho de equipa que se lhe afigurava ciclópico, o filósofo português adjudicava ao seu confrade Marcos Jorge nem mais nem menos do que a leitura das Questões Naturais de Séneca ${ }^{21}$. Possuímos no Escorial o manuscrito da atividade letiva de Marcos Jorge, mas até hoje ninguém lhe deu a atenção desejável ${ }^{22}$.

Recordemos no entanto que, tal como o referido Diógenes Laércio, Séneca é um dos primeiros autores a beneficiar da invenção de Guttenberg, com a sua mais notável edição, por iniciativa de Erasmo, logo a sair do prelo no dealbar do século XVI (1515, depois 1527-9). Embora ele não tenha sido o único estóico a receber edições modernas ${ }^{23}$, razão pela qual se pôde dizer - vamos repetir - que aquele século, mesmo independentemente da

19 Cf. M.S. de Carvalho, A Síntese Frágil Uma Introdução à Filosofia (da Patrística aos Conimbricenses), (Lisboa: Edições Colibri 2002) 57-8, com a bibliografia aí citada, nota 44.

20 Cf. Carvalho, "Introdução Geral", 22.

21 Cf. Carvalho, "Introdução Geral", 27-29, e 24.

22 Cf. Ch. Lohr, Latin Aristotle Commentaries. II: Renaissance Authors (Firenze : Leo S. Olschki 1988) 165.

23 Para só nos atermos à situação ibérica: após as edições de Erasmo, de referir a de Hernán Núñez de Pinciano (1539) para Séneca, e para Epicteto, as de Salamanca (1555) que deram início a muitas mais (vd. Constantino Láscaris Comneno, "El estoicismo em el Barroco Español”, Estudios Filosóficos 4 (1955), 325), designadamente à tradução portuguesa, editada em Coimbra em 1594, da autoria de Fr. António de Sousa (vd. Manual de Epictéto filosofo: Traduzido de Grego em linguagem portugueza por Antonio de Sousa, Bispo de Viseu, e novamente correto e illustrado com escolios e annotações criticas, Lisboa 1785, III). J.M. da Cruz Pontes refere a existência de obras senequistas traduzidas para francês, toscano, catalão e castelhano anteriores à edição de Erasmo (vd. o seu "Senequismo", in Logos. Enciclopédia Luso-Brasileira de Filosofia, Lisboa 1992, v.4, c. 1019). Vale em todo o caso a pena transcrever o testemunho coevo de Amador Arrais acerca de algumas edições de Séneca: "O peor hè que os impressores perverterão a sincera lição de muytos, \& graves autores: o que obrigou em nossos tempos a hum varão doctissimo gastar os melhores annos em emendar as obras de Seneca, Plínio, \& Mela, \& as alimpar de falsos testemunhos que impressores desalmados lhe imposerão." (Diálogos IV, 3 ; ed. M. L. de Almeida, Porto: Lello \& Ir. 1974, 223). 
notável intervenção de Lipsius ${ }^{24}$, está longe de desconhecer o estoicismo, disseminando-se sincreticamente - e para ainda não entrarmos no capítulo da moral - ser-nos-á possível elencar, numa primeira incursão provisória, algumas presenças estóicas nas páginas do Curso. A famosa senequista Epistola 15 é a primeira referência feita nas páginas publicadas ${ }^{25}$, tal como a Epistola 102, sobre a imortalidade da alma, é naturalmente citada por Baltasar Álvares por diversas vezes ${ }^{26}$. Atrevemo-nos a conjeturar que poderíamos encontrar alguns ecos do que poderia ter sido aquele trabalho de pesquisa de Marcos Jorge v.g. nos Meteoros - texto em que Séneca, a quem é atribuída uma diferente teoria sobre os meteoros ${ }^{27}$, é citado pelo menos 30 vezes $-\mathrm{e}$ ainda, e seguramente entre outros comentários mais que não tivemos tempo para compulsar, no volume do De Anima. Como se evidenciará no $\S 3$ a seguir, Séneca é particularmente citado no De Anima a propósito da visão, dos espelhos e das cores, e um tal particularismo, dada a especificidade física deste Comentário, levar-nos-ia a não ignorar v.g. a enorme informação que, via Galeno (Contra Juliano), mas também sem descurarmos a transmissão formal de Fílon de Alexandria (Alegorias das Leis, Leis especiais e Questões sobre o Génesis), se pode vir a encontrar sobre as obras médicas de Zenão, Crisipo e demais estóicos, ou a denominada "escola metódica".

Tudo somado, mas, repetimos, numa sondagem provisória e sem nos alongarmos muito, é v.g. particularmente relevante a presença da descrição galénica das quatro qualidades opostas duas a duas nos corpos vivos suportadas nos quatro humores: aos tradicionais quatro elementos corresponde a mesma quantidade de humores - atrabiliário, sanguinolento, pituitário e bilioso - e de temperamentos, respetivamente: melancólico, sanguíneo, fleumático e colérico ${ }^{28}$. Eis alguns casos mais, desde a lógica, talvez a menor presença, - pensamos v.g. nos quadrados das equipolências no âmbito das

${ }^{24}$ Cf. Lagrée, Juste Lipse, 15; Jill Kraye, "Moral Philosophy", in Ch.B. Schmitt \& Q. Skinner (ed.), The Cambridge History of Renaissance Philosophy (Cambridge: Cambridge University Press 1988) 370-72; para a receção de Lípsio em Portugal, mormente no campo do pensamento político, vd. Martim de Albuquerque, Um percurso da construção ideológica do Estado. A recepção lipsiana em Portugal: estoicismo e prudência política (Lisboa: Quetzal Ed. 2002); para a receção do estoicismo em Portugal, vd. P. Calafate, "Estoicismo em Portugal", in Logos, 1990, vol. 2, c.302-09.

${ }_{25}$ Physica, Prooemium,1.

${ }^{26}$ Tractatus de Anima Separata d. 2, a. 2, 474, e d. 2, a. 2, 477.

27 L.M. Bernardo, Histórias da Luz e das Cores. Lenda - Superstição - Magia História - Ciência - Técnica. Vol 1 (Porto: Imprensa da Universidade do Porto 2009) 76.

${ }^{28}$ Commentarii Collegii Conimbricensis Societatis Iesu, In duos libros De Generatione et Corruptione Aristotelis Stagiritae I c. 10, q. 4, a. 2 (Coimbra 1597) 359, e Commentarii Collegii Conimbricensis Societatis Iesu, In Quatuor libros de Coelo Aristotelis Stagiritae III, c. 5, q. 1, a. 1 (Lisboa 1593) 358; De Generatione et Corruptione II, c. 8, q. 4, a. 2, 461; cf. SVF II, 136-44, mais em geral. 
enunciações modais, em que literalmente se reinterpreta Aristóteles como corrigindo os antigos estóicos ${ }^{29}$ - até à moral, a que ainda voltaremos, passando obviamente, e em mais larga escala, pela física, e eventualmente pelas razões que aduzimos no início.

Assim, v.g., a ocorrência do termo lumen, sobretudo na expressão 'lume natural do intelecto', caracterizado ou como a faculdade ou capacidade de inteligir ou como uma influência no ato da ciência, independentemente do objeto inteligível e da inteleção ${ }^{30}$. Ligado ao mesmo termo, obviamente, algumas referência ao papel e ação do fogo, o mais perfeito dos elementos ${ }^{31}$ e de grau mais excelente ${ }^{32}$, ocupando o lugar cimeiro entre os restantes elementos ${ }^{33}$, dotado de uma múltipla capacidade de geração ${ }^{34}$, estando mesmo ligado à purificação do mundo ${ }^{35}$ - chega-se também a aludir à opinião sobre a duração (spatium) do grande ano ${ }^{36}$; além de se seguir Zenão de Cítio, ao mesmo tempo de Aristóteles, para se defender que o fogo está na origem das artes ${ }^{37}$, é evidente e escusado seria dizê-lo, que não se identifica sem mais o fogo/logos com a Providência (Prónoia/Eimarméne), ou o mesmo é dizer, a física com a teologia.

29 In libros Aristotelis de Interpretatione, in Dialectica II, c. 3 (Coimbra 1606) 163: “... et in primis ostendit veteres Stoicos non omnino acommodate descripsisse aequipollentium tabellas...»; ibid, 164: "Iam tradit modalium aequipollentiam prius tamen ostendit, quo pacto veteres Stoici tabellas harum propositionum constituerint."; ibid.. 167: "Monet in fine huius capitis aequipollentium tabellas accomodatius describi posse...". A estranheza é, naturalmente, de cariz histórico, mas a sua explicação filosófica deverá ser lida em Pedro da Fonseca (Instituições Dialéticas I, trad. J. F. Gomes, Coimbra 1964, 185-6): "Mas talvez alguém nos censure por lhe parecer que não seguimos nisto a Aristóteles. É que ele seguiu uma ordem muito diferente na descrição das tabelas. (...) Mas, se bem se ponderar, neste ponto, não estamos em desacordo com Aristóteles. Com efeito, o próprio Aristóteles é que deu motivo a que tenhamos mudado a ordem das enunciações e das tabelas. De facto, (...) [ele] advertiu, no fim do tratado, que eles [sc.: os quadrados da equipolência] deviam ser corrigidos para os que foram por nós ordenados." Sobre esta matéria, vd. ainda W. Kneale \& M. Kneale, O desenvolvimento da lógica, trad. (Lisboa: Fund. C. Gulbenkian 1980, $2^{\text {a }}$ ed.) 119 sg. Poderá ver-se, em particular, para Séneca, S. Wakúlenko, "As fontes dos 'Commentarii Collegii Conimbricensis e Societatis Iesu in Universam Dialecticam Aristotelis Stagiritae (1606)", Philosophia 26 (2005), 258, e The Conimbricenses. Some Questions on Signs. Translated with Introduction and Notes by John P. Doyle (Milwaukee: Marquette University Press 2001) 43.

${ }^{30}$ Physica, Prooemium, q. 1, a. 6, 13.

31 Physica IV, c. 1, q. 3, a.1, 478; cf. SVF I n. 495, 111.

32 Coelo III, c. 5, q. 2, a. 4, 366.

33 Coelo III, c. 5, q. 1, a. 2,360.

${ }^{34}$ Coelo II, c. 3, q. 7, a. 2,182; Coelo III, c. 5, q. 1, a. 3, 361.

35 Coelo I, c. 1, q. 1, a. 1, 7; cf. SVF II, 183-91 em geral.

${ }^{36}$ De Generatione et Corruptione II, c. 11, q. 1, a. 1, 488.

${ }^{37}$ Coelo III, c. 5, q. 2, a. 3, 366. 
Temos depois um acolhimento explícito à doutrina das razões seminais ${ }^{38}$, chegando mesmo a ler-se que os teólogos conhecem as formas segundo as razões seminais ${ }^{39}$, nas quais como que estão contidos em sementes os efeitos naturais ${ }^{40}$. E ainda a afirmação, sem dúvida alguma mais importante, de que a mútua ação dos contrários na natureza é como que uma lei ${ }^{41}$. Uma vez que o conflito entre os elementos enquanto contrários físicos não só não perturba a ordem do Universo como é por esta requerida ${ }^{42}$ - a razão pela qual na ordem da natureza há sempre contrários deve-se ao facto de assim se obter uma perfeição maior e uma outra menor ${ }^{-43}$, leva a falar-se de um fim na mútua concertação entre os elementos ${ }^{44}$, a propor uma concórdia discordante nos quatro elementos ${ }^{45}$. Ou por outras palavras: as qualidades primeiras inerem em qualquer elemento numa coerência de concórdia discordante ${ }^{46}$ e de ressarcimento de dispêndios ${ }^{47}$.

Ligado ainda a este motivo, a noção de beleza nas coisas criadas, não tanto como esplendor de uma coisa que apenas visto atrai a alma ${ }^{48}$, mas sobretudo como composição adequada entre tudo aquilo que tem uma ordem entre si, patente v.g. na 'harmonia do mundo', ao nível dos seus elementos e da hierarquia entre os corpos naturais ${ }^{49}$, e também, como dissemos já, da discordância e da variedade ${ }^{50}$. É a concórdia discordante e a amizade dos opostos que integra a conservação, a ordem e a beleza dos elementos do mundo, sendo precisamente por causa da semelhança na dissemelhança, frisa o CAJC citando $O$ Mundo, que o cosmos não perece, ainda que contido por contrários ${ }^{51}$. Todo o esforço (conatus) da natureza visa o bem comum ${ }^{52}$, sem tender para o

38 Physica I, c. 9 , q. 12 , a. $6,208$.
39 Physica I, c. 9 , q. 12 , a. $1,202$.
40 Physica I, c. 9 , q. 12 , a. $6,208$.
${ }^{41}$ De Generatione et Corruptione I, c. 9 , q. 3, a. 2, 330; cf. Séneca, Questions Naturelles VII 27, 4 (Texte établi et traduit par Paul Oltramare, Tome II, Paris: PUF 1929) 329: "tota haec mundi concordia ex discordibus constat".

42 Coelo I, c. 1, q. 1, a. 6, 13.

43 Coelo II, c. 3, exp.153.

${ }^{44}$ Coelo I, c. 1, q. 1, a. 1, 7.

45 Physica II, c. 9, q. 1, a. 1,351; Physica IV, c. 1, q. 3, a. 1, 479.

46 De Generatione et Corruptione II, c. 3, q. 5, a. 1, 391.

${ }^{47}$ De Generatione et Corruptione II, c. 3, q. 5, a. 1, 392.

48 Physica I, c. 9, q. 4, a. 1, 169.

49 Tractatio aliquot Problematum de rebus ad quatuor mundi elementa pertinentibus in totidem sectiones distributa, in Coelo s. 2, 412.

${ }^{50}$ Commentarii Collegii Conimbricensis Societatis Iesu, In libros Meteororum Aristotelis Stagiritae t. 3, c. 1 (Lisboa 1593) 25, e ibid. t. 8, c. 7, 85.

${ }^{51}$ De Generatione et Corruptione II, c. 3, q. 5, a. 1, 391.

52 Physica IV, c. 9, q. 1, a. 3, 508. 
mal ${ }^{53}$, ela segue o melhor e o mais útil ${ }^{54}$, porque é presidida por uma intenção ${ }^{55}$ e, não obstante óbvias debilidades ${ }^{56}$, é amiga do equilíbrio (aequabilitas) ${ }^{57}$, bela ${ }^{58}$, sendo ainda dotada de sagacidade e providência próprias ${ }^{59}$. Tudo isto atesta a vigência de uma teleologia ou determinação para o maximamente uno e determinado no Universo ${ }^{60} \mathrm{e}$, parece-nos, ocorre, como dissemos, mediante uma leitura mais do que aristotélica. Sendo a obra da natureza uma obra da inteligência ${ }^{61}$, como primeira causa ${ }^{62}$, todo o fim da natureza visa a ordem e a conservação das coisas ${ }^{63}$, tal como a obra do intelecto consiste em ordenar ${ }^{64}$. Definida por Agostinho como a disposição dos seres iguais e desiguais que distribui a cada um os seus lugares, a ordem é a inclinação para o bem e o fim próprio de cada coisa ${ }^{65}$ - aliás, ordem e inclinação de cada coisa são o mesmo ${ }^{66}$ - e o que a caracteriza é a razão e a proporção ${ }^{67}$.

Por fim, no capítulo da antropologia, como diríamos hoje, deparamo-nos com a teoria do Homem-microcosmos, pequeno mundo (parvus mundus), como aparece designado em múltiplas passagens ${ }^{68}$, a parte mais nobre (nobilissima) do mundo ${ }^{69}$, o fim do mundo corpóreo $^{70}$, ou o fim da natureza

${ }^{53}$ De Anima II, c. 1, q. 3, a. 2, 58; De Generatione et Corruptione I c. 4, q. 16, a. $5,125$.

54 Coelo II, c. 5, exp. 207.

55 De Generatione et Corruptione I, c. 4, q. 16, a. 4, 123.

${ }^{56}$ Coelo II, c. 6, exp. 241.

57 Coelo II, c. 12, exp. 297.

${ }^{58}$ Physica II, c. 9, q. 1, a. 1, 350.

${ }^{59}$ De Generatione et Corruptione I, c. 9, q. 3, a. 5, 337.

${ }^{60}$ Coelo I, c. 2, q. 1, a. 2, 21 ; cf. SVF II, 170.

${ }^{61}$ Physica II, c. 9, q. 2, a. 2, 358.

62 Physica II, c. 9, q. 4, a. 3, 368.

${ }^{63}$ Physica II, c. 9, q. 1, a. 1, 350.

${ }^{64}$ Physica II, c. 9, q. 2, a. 3, 359.

65 Coelo I, c. 1, q. 1, a. 5, 12.

${ }^{66}$ Coelo III, c. 2, exp. 346.

${ }^{67}$ Physica VIII, c. 2, exp. 703.

${ }^{68}$ Physica VIII, c. 2exp. 704; Coelo I, c. 1, q. 2, 8-9; De Generatione et Corruptione I, c. 5, q. 1, a. 1, 208 Physica VIII, c. 2, exp. 705; cf. M. S. de Carvalho, «O Lugar do Homem no Cosmos ou o lugar do cosmos no Homem? O tema da perfeição do universo antes do paradigma do mundo aberto, segundo o comentário dos jesuítas conimbricenses» Veritas 54 n. 3 (2009) 142-155.

${ }^{69}$ Anima II c. 1, q. 3, a. 2, 58; sobre a própria beleza da alma - quer na sua composição, quer na sua ordenação, como quando o apetite irascível e o concupiscível se submetem à vontade, a vontade à razão e a razão à lei eterna, motivo que pode inclusivamente ofuscar a própria beleza física como não verdadeira (Coelo II, c. 8, q. 3, a. 3, 454).

${ }^{70}$ Coelo II, c. 14 , q. 4, a. 3, 333. 
corpórea $^{71}$, havendo uma relação de conveniência entre o mundo menor, que o Homem é, e o mundo maior, todo o universo, aquele regendo-se pelos espíritos animais e vitais, este pelos espíritos celestes ${ }^{72}$.

E da antropologia, e antes de passar para a ética no $\S 4$, haveria só que apresentar o acolhimento dado à teoria da consciência original, ou sindérese, na latinização de São Jerónimo. Tratando-se de uma disposição do intelecto, e não da vontade - pois tende para o bem, não em si, mas apenas sob a noção da verdade prática que é objeto do intelecto -, designada pelos Padres por 'centelha da razão' ou 'juízo natural' que nunca se extingue, compete-lhe julgar o que é e o que não é reto ${ }^{73}$. Articulada com a doutrina do lume da razão natural, a sindérese é uma santidade natural que existe na alma humana, impressa por Deus, quer dizer, uma centelha da consciência não congénita, mas adquirida ${ }^{74}$.

$\S 3$. A teoria da visão do Curso Jesuíta Conimbricense encontra-se explanada no Capítulo VII do Livro II do Comentário ao 'De anima', da autoria de Manuel de Góis. Este acervo teórico manifesta uma clara adesão a Aristóteles e à tradição peripatética mitigada pela influência médica, sobretudo de Galeno, autor muito em voga aquando da elaboração do Curso, estudado na Universidade de Coimbra, inclusive em grego, nas aulas de António Luís. ${ }^{75}$ Aquela teoria integra uma componente técnica e científica mas propõe-se alcançar um escopo mais amplo, dirigido ao homem no seu todo, procurando explicar de que forma o ato de ver pode ser instrumento da salvação da alma, suscitar o aperfeiçoamento ético e favorecer o conhecimento de si.

Nos primeiros séculos do cristianismo e até ao século XII o ocidente cristão foi marcado, no campo da Ótica e do estudo dos fenómenos naturais e atmosféricos em geral, pelo Comentário de Calcídio ao Timeu de Platão e respetiva tradução parcial, pelas Questões Naturais de Séneca, pela História Natural de Plínio e pelo capítulo XI do Da Trindade de Santo Agostinho que condicionaram para a posteridade a formulação de grande parte das doutrinas sobre a visão. ${ }^{76}$ Esta tradição perdurou até ao Renascimento ainda que

71 Physica II, c. 9, q. 2, a. 1, 357.

72 Coelo II, c. 5, q. 5, a. 3, 229.

73 Commentarii in libros Aristotelis Stagiritae de Posteriore Resolutione I, c. 1, q. 1, a. 4, in Dialectica 296.

${ }^{74}$ De Posteriore Resolutione I, c. 1, q. 1, a. 4, 300.

75 António Guimarães Pinto, "Introdução", in António Luís. Cinco Livros de Problemas. Tradução de A. G. Pinto (Lisboa: Centro de Filosofia da Universidade de Lisboa 2010), 35 .

76 Sobre esta matéria veja-se D. C. Lindberg, Theories of Vision from Al-Kindi to Kepler (Chicago London: The University of Chicago Press 1976) 88-90; Ma da C. Camps; "As teorias da visão no ocidente medieval até ao século XII. O Comentário de Calcídio 
modificada e aperfeiçoada de acordo com os sucessivos avanços e descobertas que ocorreram ao longo dos séculos, sendo responsável pela transmissão de influências galénicas e neoplatónicas.

A teoria da visão de Manuel de Góis, no que toca à descrição da forma como ocorre o ato de ver, é explicada a partir da Questão V do Capítulo VII do referido Livro II, ainda que no volume do curso onde esta obra se insere subsistam outros textos sobre a matéria, como Os Problemas, atribuídos a Cosme de Magalhães, editados em anexo ao Comentário ao 'De anima', que também incluem um capítulo sobre a visão. ${ }^{77}$

A explicação do fenómeno visual propriamente dito inscreve-se, como dissemos, no Capítulo VII, a partir da Questão V, onde é estudada a relação entre o sentido e o sensível, e nas Questões VI e VII, que se centram na descrição dos órgãos do corpo responsáveis pelos mecanismos da visão. As questões VIII e IX completam o quadro clássico de uma abordagem deste tipo, desta feita acercando-se da catótrica e da problemática da descoberta das águas no subsolo por parte dos denominados vedores.

$\mathrm{O}$ estudo começa com a controvérsia relativa à opinião de diversos filósofos, sobretudo a de Platão. No mesmo $\operatorname{artigo}^{78}$ são apresentados os argumentos a favor de Platão e dos seus seguidores, bem como os de outras teorias, nomeadamente dos atomistas. ${ }^{79}$ Nesta mesma questão é enfatizado o papel do meio e o das espécies sensíveis, predominando a doutrina fundada na tradição aristotélica e defendida pela escola peripatética, que é, segundo Manuel de Góis, a que detém a posição verdadeira acerca do assunto. A visão ocorre a partir das imagens (imagines) emitidas pelo objeto. Estas afluem aos olhos num meio transparente em ato. Os corpos coloridos e translúcidos manifestam a luz e a sua semelhança no espaço, produzindo as espécies. As espécies resultam do movimento do diáfano devido à presença daqueles corpos, de acordo com a interpretação feita do passo de Aristóteles que diz que é o movimento do meio que provoca a visão. ${ }^{80}$

ao Timeu de Platão e As Questões naturais de Adelardo de Bath", Philosophica 34 (2009), 231-243.

77 Tractatio aliquot Problematum ad quinque sensus spectantium per totidem sectiones distributa, in De Anima 533-558.

78 De Anima II, c. 7,q. 5, a. 1, 178-9.

${ }^{79}$ Encontramos também, uma referência a Séneca, aqui colocado no grupo dos extramissionistas. Provavelmente devido à opinião defendida por este autor em As Questões Naturais, Livro II, IX.1, na sequência da descrição do denominado impetus, em VIII, que anima certos corpos da natureza: "Ostendit intentionem spiritus uelocitas eius et deductio. Oculi statim per multa nilia aciem mittunt; uox una tota urbes simul percutit; lumen non paulatim properit sed semel uniuersis rebus infunditur" Vd. Séneca, Questions Naturelles, 62.

${ }^{80}$ Aristóteles, O Sentido e o Sensivel, II 438b. 
Deparamo-nos seguidamente com uma reflexão sobre a excelência da visão, o simbolismo da posição dos olhos no corpo, a sua forma, o seu papel como espelho da alma e como lugar de paixões. Ali também são feitas analogias entre a mente e a visão e considerações de natureza moral. ${ }^{81}$ Segue-se o tratamento de questões de ordem fisiológica e médica e a descrição do funcionamento do aparelho visual. ${ }^{82}$

$\mathrm{O}$ relevo dado à catótrica ${ }^{83}$ denota a influência dos Perspetivos, ao mesmo tempo que cumpre a tradição, dominante desde a Antiguidade, de colocar como lugar obrigatório desta disciplina o tratamento da visão nos espelhos. Séneca nas Questões Naturais é certamente o principal responsável pela fundação desta tradição. A última questão remete-nos para a problemática dos denominados vedores. Como é apontado na respetiva questão, Plínio já com ela se preocupara na sua História Natural. ${ }^{84}$

\section{$\S$ 3.1. O animus e o corpus da teoria da visão conimbricense}

Se examinarmos atentamente, verificaremos que o Capítulo VII do Comentário ao' De Anima' de Aristóteles, no que à visão concerne, se encontra edificado em dois níveis ou patamares. Um, primeiro, que designaremos por corpus. Numa abordagem tradicional diremos que o corpus é o conjunto de posições doutrinárias que explicam o paradigma da visão ao nível psicofisiológico, matemático e físico, incluindo a componente médica. O corpus da visão envolve o exame e a descrição das partes do corpo responsáveis por esta função, o funcionamento do aparelho ocular, o modo como a visão se dá, o estudo das doenças oftalmológicas e o respetivo tratamento. Para sua cabal compreensão deve ser tida em conta também a matéria ínsita nos Problemas sobre a visão, como acima referimos ${ }^{85}$. Concluímos que o Comentário aponta para um corpus teórico de tradição peripatética mas com posições doutrinárias próprias que demonstram acolher as mais recentes aquisições no

${ }^{81}$ De Anima II, c.7, q. 6, a.1, 184.

82 De Anima II, c.7, q. 6, a.2, $185 \mathrm{sg}$.

${ }^{83}$ De Anima II, c.7, q. 8, a. 2, 191-3.

${ }^{84}$ De Anima II, c.7, q. 9, a. 1, 194.

85 Este opúsculo conimbricense aparece na tradição da obra homónima atribuída a Aristóteles, ainda que esta atribuição seja duvidosa, pelo menos na sua totalidade. $\mathrm{O}$ texto aristotélico que hoje possuímos resulta da combinação de textos de vários períodos. Presume-se que alguns sejam de Aristóteles, outros da Escola, mas não necessariamente do Estagirita. Este tratado foi traduzido várias vezes ao longo da Idade Média. A tradução mais importante foi a de Bartolomeu de Messina, no século XIII, da qual foram feitas cópias. Pedro de Abano foi o autor do Comentário publicado no século XIV. No século XV surgiram as traduções de Teodoro de Gaza e de Jorge Trebizonda, sendo mais conhecida a de Gaza. Esta obra ficou notável devido também aos abundantes Comentários médicos a que deu origem. 
terreno da Ótica, designadamente as da Ótica geométrica dos Perspetivos a partir do século XIII, como Vitélio, Ciruelo, Vesálio e Peckham, ${ }^{86}$.

Um segundo patamar eleva-nos a um nível de abordagem do tema mais próximo de um animus, ou seja, do conjunto de razões subjacentes ao ato de ver e ao modo como ele decorre, ainda que as mesmas nem sempre se encontrem expressas. Desta feita, interrogaremos os seus fins próximos, que concitam o domínio da ética, e os últimos, que indagam até que ponto "o ver" pode consubstanciar um ato salvífico, ou, pelo contrário, enquanto lugar de paixões, poderá conduzir à perdição da alma. Ou seja, se a visão é a rainha dos sentidos externos e o mais espiritual de todos eles, há que questionar até que ponto ela pode, ou não, ser uma via entre o sensível e o inteligível, entre o material e o espiritual, entre o homem e Deus. Neste contexto é analisado o drama da chamada imperfeição humana, das escolhas, do livre arbítrio, já que pela visão se pode aceder à virtude ou acolher os vícios mais torpes. Segundo Manuel de Góis, a visão ordenada pela Ética, pode propiciar o conhecimento de si. A natureza, leia-se, a obra de Deus, não faz nada em vão, tudo está ordenado, tudo tem um fim que aponta para a salvação, mas compete ao homem alcançá-la, ou não, na medida das suas escolhas. Conhecer a natureza é desvendar Deus, e a visão é o sentido mais idóneo para cumprir esta tarefa. ${ }^{87}$

Santo Ambrósio, Fílon de Alexandria e Platão são os autores chamados a proclamar a excelência e a superioridade da visão, remetendo para segundo plano as passagens homólogas de $O$ Sentido e o Sensivel e do livro $D a$ Alma de Aristóteles. ${ }^{88}$ Nestes textos, Aristóteles afirma que a visão é o mais importante de todos os sentidos externos em ordem à satisfação das necessidades do homem, tendo reservado o tratamento da excelência para o passo citado do Da Alma. Mas não é esta excelência que Manuel de Góis regista no Artigo I da Questão VI, mas sim a excelência que conduz o homem à superação de si mesmo, numa vivência das funções superiores da alma. A visão transforma-se num sentido intelectual e espiritual, apelando para as funções da alma que apenas ao homem dizem respeito, demarcando-se da 'visão aparelho fisiológico' partilhada com os outros animais. A passagem da alma sensitiva para a alma intelectiva, para usarmos o quadro aristotélico

${ }^{86}$ De Anima II, c.7, q. 7, a. 2, 188-9 e ibidem q. 8, a. 2, 191, por exemplo, onde são citados estes autores.

${ }^{87}$ De Anima II, c.7, q. 6, a. 1, p.184. Para mais desenvolvimentos, vd. $\mathrm{M}^{\mathrm{a}}$ da C Camps, Do visivel ao Invisível: a teoria da visão no comentário aos três livros 'Da Alma' do Curso Jesuita Conimbricense (1598), Tese de Doutoramento em filosofia apresentada à Universidade do Porto ( 2012), consultável em http://aleph.letras.up.pt/F?func=find-b\&find_code $=$ SYS\&request $=000222878$

${ }^{88}$ Aristóteles, O Sentido e o Sensivel 437 a5 e Da Alma 429 a 2, respetivamente. 
que serve de pano de fundo à teoria da visão coimbrã, realiza-se também pela visão quando esta transcende a sua função estritamente fisiológica para cumprir um desígnio mais nobre, o da condução do homem a um patamar superior da existência.

$\S$ 3.2. A presença do estoicismo no capítulo VII do livro II do Comentário ao De anima

O estoicismo ingressou na teoria da visão conimbricense por duas vias. Uma, primeira, recebida da tradição do estudo da Ótica, onde deu cartas desde a Antiguidade e onde permaneceu ininterruptamente até ao século XVI, muitas vezes mitigada por outras correntes teóricas e adaptada por autores que utilizaram o acervo doutrinal estóico para construir as suas próprias explicações sobre o fenómeno da visão, como é o caso de Galeno. Aqui, diríamos, o estoicismo foi recebido per substratum, tendo integrado a teoria da visão conimbricense como um criptotexto de ordem científica.

Uma, segunda, fruto do seu próprio tempo, do século XVI, período em que as correntes filosóficas de inspiração estóica e o conjunto de obras editadas, graças aos alvores da imprensa, designadamente as de Séneca, forneciam material pronto a ser utilizado pela Filosofia.

A explicação da visão estóica parte do conceito de pneuma ótico, agente ativo que fluindo do cérebro (hegemonikon) até aos olhos excita o ar adjacente colocando-o numa situação de tensão. Esta tensão ou tónus transforma o ar num agente precioso, meio pelo qual a visão ocorre, uma vez iluminado pela luz solar e ocorrido o contacto com o objeto da visão. A ação simultânea do pneuma e da luz solar transforma o ar num agente da alma. O próprio ar será uma espécie de extensão do olho nas suas funções de perceção. A tensão produzida pelo ar, assemelhar-se-á para alguns estóicos como Crisipo, a um bastão que, sacudindo o visível capta a imagem e a transmite à vista do observador. ${ }^{89}$ Haverá lugar a um cone visual, na sequência do ato de ver, cujo vértice se situa nos olhos do observador e a base no objeto avistado.

A ênfase colocada no meio, ar, coloca a explicação estóica no grupo daquelas teorias que acentuam o papel do meio no processo visual como é o caso das de Platão e de Aristóteles e que, sobretudo graças a esta última, virá a constituir uma poderosa corrente, principalmente no campo da tradição médica.

A teoria estóica será perfilhada e adaptada por Galeno em ordem à construção da sua própria ciência da visão. Esta preferência galénica teve grande produtividade já que encetou uma tradição que perdurou por longos séculos, alcançando a modernidade. Galeno acolheu o «pneuma» e o «ar iluminado», ainda que não desdenhasse, pela importância dada ao meio, o ensinamento

89 Vd. Diógenes Laércio, SVF, II, 867; Alexandre de Afrodísia, SVF, II, 864, 233. 
de Aristóteles sobre o diáfano. Criticou certas interpretações do «báculo» que alguns estóicos, no seu dizer, advogavam como instrumento da visão, preferindo as correntes que consideravam o ar um prolongamento do órgão da visão:

$\mathrm{Si}$ igitur visus solus ex aliis sensibus percipit sensile, quod ipsum movet, per medium aerem, non ceu per baculum quendam, sed partem consimilem specie et cognatam ipsi, ac soli hoc ipsi eximium datum est, simul quod per reflexum videt, merito opus habuit spiritu desuper influente pellucio, qui alienti aeri incidens et veluti converberans ipsum sibi assimilabit. ${ }^{90}$

Persimili quid etiam in aere nos ambiente accidit, nam illuminatus a sole tale jam est nobis visus instrumentum qualis ex cerebro proficiscens spiritus $(\ldots)^{91}$ Visus autem per nervos visorios exiliens, quum substantiam habeat spiritalem, ubi in ambientem incidit, primo incursu alterationem efficiens ac se quam longissime extendens, illuminat quod illi continuum est, nempe quod ambit corpus: sic ut in momento temporis alterationem in totum ipsum transmittat. Apparet autem similis quidam affectus utique accidere, nervo, ambienti aeri. Persimili quid etiam in aere nobis circunfluo accidit. Nam illuminatus a Sole, tale iam est nobis visus instrumentum, quale ex cerebro proficiscens spiritus. ${ }^{92}$

A transmissão de Galeno ao Ocidente cristão fez-se, tal como a de Aristóteles, por via arábica, mas não de uma forma completa. ${ }^{93}$ Foram sobretudo os médicos que também desenvolveram o estudo da Ótica, que frequentaram as suas obras. O principal divulgador e tradutor de Galeno foi, no século

${ }^{90}$ Claudii Galeni Opera Omnia, v. 5 (Lipsiae, 1823), Ed. Karl Gottlob Kühn, $2011, .627$.

91 Claudii Galeni Opera Omnia, v. 5, 642.

92 Epitomes Omnium Galeni Pergami Operum Sectio Prima per Andream Lacunam Secobiensiem, Lugduni, apud G. Rouillium, sub Scuto Veneto, 1553, 937.

93 Para a transmissão da obra de Galeno e respetivas traduções, vd. Danielle Jacquart e Françoise Micheau, La médicine arabe et l' Ocident médeival (Paris: Éditions Mainsonneuve et Larose, 1996) designadamente 36- 37 e 147-153. Também a obra de Aristóteles teve vários ingressos no ocidente europeu. $\mathrm{O}$ primeiro aconteceu com as traduções de Boécio; o segundo, nos finais do século XII, inícios do século XIII, por via arábica; o terceiro, onde se integra o presente Curso, comparece nos alvores da imprensa, com a onda de traduções novas sobre textos já conhecidos, mas também com a impressão de textos até aí desconhecidos que deram ao prelo obrigando à renovação de reflexões sobre as matérias. Para a receção da obra de Aristóteles no ocidente, vd. Bernard G. Dod, «Aristoteles Latinus», in The Cambridge History of Later Medieval Philosophy (Cambridge New York: Cambridge University Press, 1984), 45-79; também L.A. De Boni, A Entrada de Aristóteles no ocidente medieval (Porto Alegre: Est 2010) passim; L. Bianchi, «Continuity and Change in the Aristotelian Tradition», in J. Hankins (ed.), The Cambridge Companion to Renaissance Philosophy (Cambridge New York: Cambridge University Press 2007), 49-71. 
IX, Hunain ibn Ishaq (Ioannitius), cristão nestoriano da Mesopotâmia, sírio de língua materna mas bilingue. Celebrizou-se como professor de medicina e tradutor. Tomou conhecimento de 51 obras de Galeno que haviam sido vertidas para sírio por Sergius de Ra's al- 'Ain e por Ayyub ar- Ruhaw, tendo efetuado uma nova tradução das mesmas, também para sírio, compulsando o texto grego. Além destas, traduziu para a mesma língua mais 43 outros tratados e verteu outros dez, do grego para o árabe. A tradução efetuada para o árabe foi adaptada e resultou numa obra de tipo enciclopédico sobre os princípios fundamentais de Galeno baseada na Ars Medica (Techne iatrike) conhecida no ocidente como Ysagoge Ioanitti ad Tegni Galeni. A Ysagoge esteve na origem de uma coleção de escritos médicos utilizados nas universidades desde o século XIII ao século XVI, como manual. A Universidade de Salerno adicionou outros tratados médicos à Ysagoge. Esta coleção de textos médicos ficou conhecida por Articella, cuja última versão incluiu a Ysagoge ad Artem Galeni de Ionattius, os Aforismos e Prognósticos de Hipócrates, o De urinis de Teófilo, o De pulsibus do Filareto e o Tegni ou Ars Parva de Galeno. ${ }^{94}$

Hunain apresenta uma explicação da visão muito próxima da estóico-galénica. O espírito visual ao sair da vista atinge o ar provocando uma modificação no meio que propicia a visão. Não há uma propagação do espírito visivo tal como é descrito pelos extramissionistas mas uma transformação alcançada pelo ar adjacente. ${ }^{95}$

Constantino, o Africano, no século XI, em Monte Cassino, verteu para latim a Ysagoge tornando-se o primeiro responsável pela transmissão de Galeno ao ocidente latino. Gerardo de Cremona e Burgúndio de Pisa, no século XII, também traduzirão e divulgarão Galeno. Arnaldo de Vilanova, médico, em 1290 encontrou o De locis affectis e em 1330 escreveu uma sinopse da obra, tendo ainda estudado pelo menos quatro outras obras. Com base nestas construiu uma teoria sobre os sentidos internos. ${ }^{96}$ É de realçar o papel do Conciliator de Pedro de Abano (1250-1315) na difusão da literatura médica galénica no ocidente.

As obras não adaptadas de Galeno só serão vertidas para latim e divulgadas integralmente durante o Renascimento, designadamente o De Placitis Hippocratis et Platoni ${ }^{97}$.

94 Danielle Jacquart, "AristotelianThought in Salerno", in Dronke (ed.) A History, 412.

95 Sobre esta matéria veja-se Lindberg, Theories of Vision, 33-42.

${ }^{96}$ Michael McVaugh, "Arnaldo de Vilanova “ The Pathology of Cognition"”, in Graziella Federici Vescovini et al. (ed.), Corpo et Anima, Sensi Interni e Intelleto dai Secoli XIII-XIV ai Post-Cartesiani e Spinoziani (Turnhout: FIDEM 2005) 134-135.

97 As reedições de Galeno foram muitas durante o Renascimento tendo a sua doutrina sido incorporada pelos principais médicos do tempo de que é exemplo entre nós 
A transmissão de Galeno ao ocidente deu origem a um conjunto de doutrinas com grande fortuna. A teoria da visão conimbricense é uma das herdeiras desta tradição, designadamente quando afirma que sem os espíritos visivos não ocorre a visão. A alteração dos espíritos poderá mesmo dar origem a disfunções, como acontece nos ébrios e nalgumas patologias oftalmológicas específicas. $\mathrm{O}$ aristotelismo galenizado transporta um acervo estóico inimpugnável no campo da medicina e da visão. Neste sentido, incluímos este criptoestoicismo recebido per substratum, no âmbito daquilo que designámos por corpus da teoria da visão conimbricense. O texto que se segue é elucidativo:

Concurrunt etiam ad oculi structuram duo nerui, qui optici, seu uisorii appellantur: hi uero a cerebro proficiscuntur, alter e dextera parte, alter e sinistra: sed aliquantulum progressi inter se coeunt, rursumque antequam oculos subintrent, separantur: et quia duplici membrana uestiti sunt; interna tenui, et externa dura; ex illis ortum habent duae tunicae, uuea et cornea; Per eos simulachra rerum, quae sub aspectum cadunt, in communem sensum influunt, simulque per eosdem a cerebro emicant uisorii spiritus, sine quorum ope facultas cernendi munus suum obire nequeat. Hinc est quod affecto cerebro, etsi oculi nihil aliunde incommodi patiantur, hebescit uisus, ut patet in ebriis, deliris, et phreneticis, e quorum cerebro desiliunt spiritus nebulis obducti, ac minus puri minusque apti ad operationem. ${ }^{98}$

Mas Galeno também foi conhecido através das obras integrais entretanto publicadas e que são nomeadas no curso ${ }^{99}$.

O texto conimbricense, e ainda no âmbito do corpus, se bem que não per substratum, assinala uma referência explícita aos estóicos. Tal ocorre na sequência da discussão sobre a probabilidade de os denominados vedores poderem ver, ou não, as águas existentes no subsolo. Ainda que Plínio seja o autor mais citado graças à sua popularidade na divulgação dos mirabilia naturais, a ciência estóica sobre a natureza é preferencialmente acolhida:

Qui negatiuam partem sequuntur, ea, quae diximus experimenta ad externa signa, ad mendacia, ad ueneficia, ad casum referunt. Si qui tamen affirmatiuam sequi uoluerint, ad primam aduersariorum rationem respondebunt cum Stoicis, terram quidem opacam, et obscuram esse, non quia nihil prorsus

Tomás da Veiga.Em 1525 é publicada a edição Aldina com as suas obras em grego, vd. Anthony Grafton, «The availability of Ancient works», in Charles B. Shmitt et alii (ed.), The Cambridge History or Renaissance Philosophy (Cambridge- New York: Cambridge University Press 1988), 782.

${ }^{98}$ De Anima II, c.7, q. 6, a. 2, 186.

99 De Anima.II, c.7, q. 7, a. 2, 189. A título de exemplo assinalem-se as referências expressas ao De usu partium e ao De locis affectis, a propósito do mecanismo e fisiologia da visão. 
luminis interius saltem intra poros admittit, sed quia id adeo exiguum est, ut pro nihilo habeatur; praesertim cum ordinarie sub aspectum non cadat. Non uidere autem aquileges aquam sine aliquo lumine, argumento est, quod aquam exploraturi meridianam lucem querunt, et solis splendorem, quo nimirum a profundo species hauriant, et ad aspectum euocent. Quae species per aerem poris terrae contentum forte traiiciantur. ${ }^{100}$

Há uma grande variedade de opiniões sobre este assunto, segundo Manuel de Góis, subsistindo os que negam a possibilidade de ver através da terra porque ela é opaca, considerando ser impossível visualizar o que se passa no seu interior. Outros, afirmando que a opacidade é relativa e que a luz subsiste nos poros da terra, como dizem os estóicos e, por isso, os vedores, dotados de um olhar especial, usando a luz do meio-dia e o esplendor do Sol, conseguiriam receber as espécies que atravessam o ar, arremessadas pelos poros terrestres.

A questão não é conclusiva quanto ao facto de se saber se os vedores veem, ou não, de facto, por meio da acuidade visual propriamente dita ou derivada da capacidade de descobrir águas no subsolo através de outros sinais exteriores. A resolução do assunto será remetida para juízos de probabilidade ${ }^{101}$.

Constatamos também a presença de posições estóicas assumidas no âmbito do que denominámos de animus da teoria da visão conimbricense. A autoridade de Séneca é manifesta e expressa no campo da Ética. Tal é evidente na catótrica, aquando da discussão do fundamento da possibilidade concedida ao homem de contemplar a sua própria figura, de ver a sua própria imagem, bem como dos riscos decorrentes de tal visão para a salvação da alma.

A visão nos espelhos, é referido, também existe para que nos conheçamos melhor, já que dá acesso à imagem do próprio corpo, à fisionomia. Como é afirmado, Sócrates usava os espelhos para disciplinar os costumes. O texto de Séneca é citado como podemos constatar no seguinte quadro:

${ }^{100}$ De Anima II, c.7, q.9, a. 2, 196; os sublinhados são nossos

101 Sobre o tratamento dos juízos de probabilidade por parte dos autores do Curso, vejam-se as posições de Alfredo Dinis, "Tradição e transição do 'Curso Conimbricense"” Revista Portuguesa de Filosofia 47 (1991) 546-559, onde a probabilidade aparece como sinal ou índice do surgimentos de novas explicações em confronto com as até aí aceites. 


\begin{tabular}{|c|c|}
\hline Texto de Góis & Texto de Séneca \\
\hline $\begin{array}{l}\text { Hinc Socrates, ut Apuleius refert, } \\
\text { speculo ad morum disciplinam utebatur, } \\
\text { idque etiam adolescentibus, ut facerent, } \\
\text { praecipiebat; quo si liberali forma essent, } \\
\text { ne illam uitiis contaminarent, si deformi } \\
\text { specie, eam morum elegantia compensarent. } \\
\text { Quo spectat illud Senecae Naturalium } \\
\text { quaestionum lib. 1. cap. 17. Inuenta } \\
\text { sunt specula non ut barbam, faciemque } \\
\text { uelleremus, aut ut faciem uiri poliremus, } \\
\text { sed ut homo ipse se nosceret. Multi ex hoc } \\
\text { consequuti sunt primo sui notitiam, deinde } \\
\text { et quoddam consilium; formosus, ut uitaret } \\
\text { infamiam; Deformis, ut sciret rendimendum } \\
\text { esse uirtutibus: quicquid corpori deesset. } \\
\text { Iuuenis, ut flore aetatis admoneretur, illud } \\
\text { tempus esse discendi, et fortia audendi; } \\
\text { senex, ut indecora canis deponeret, et de } \\
\text { morte aliquid cogitaret. Ad hoc rerum } \\
\text { Natura facultatem nobis dedit, nosmetipsos } \\
\text { uidendi. Fons cuique perlucidus, aut laeue } \\
\text { saxum imaginem reddit. Nuper me in } \\
\text { littore uidi. Cum placidum uentis staret } \\
\text { mare. Qualem fuisse cultum putas ad } \\
\text { hoc speculum se cernentium? Aetas illa } \\
\text { simplicior, et fortuitis contenta, nondum in } \\
\text { uitia beneficium detorquebat, nec inuentum } \\
\text { naturae in libidinem, luxumque rapiebat. }\end{array}$ & $\begin{array}{l}\text { Inventa sunt specula ut homo } \\
\text { ipse se nosset, multa ex hoc consecuturus, } \\
\text { primum sui notitiam, deinde ad quaedam } \\
\text { consilium: formosus, ut uitaret infamiam; } \\
\text { deformis, ut sciret redimendum esse } \\
\text { uirtutibus quicquid corpori deesset; } \\
\text { iuuenis, ut flore aetatis admoneretur illud } \\
\text { tempus esse discendi et fortia audendi; } \\
\text { senex, ut indecora canis deponeret, ut de } \\
\text { morte aliquid cogitaret. Ad haec rerum } \\
\text { natura facultatem nobis dedit nosmet } \\
\text { ipsos uidendi. Fons cuique perlucidus } \\
\text { aut leue saxum imaginem reddit: nuper } \\
\text { me in litore uidi. Cum placidum uentis } \\
\text { sataret mare. Qualem fuisse cultum } \\
\text { putas ad hoc se speculum comentium? } \\
\text { Aetas illa simplicior et fortuitis contenta } \\
\text { nondum inuitium bebnefcia detorquebat } \\
\text { nec iuenta naturae in libidinem luxumque } \\
\text { rapiebat. }{ }^{2}\end{array}$ \\
\hline
\end{tabular}

Há uma clara indicação da finalidade, da razão última que subjaz à existência dos espelhos, à possibilidade de reflexão das imagens, devolvendo a figura ao olhar - o aperfeiçoamento da natureza humana, da sua moral, em ordem a ajudar o homem a tomar consciência da sua própria imperfeição e finitude com base nos ensinamentos retirados da visão de si. Bela, feia, jovem, velho "foi para isto que a natureza das coisas nos deu a faculdade de nos vermos a nós mesmos". A visão propicia a correção dos desvios, a compensação dos pontos menos bons da figura, da fisionomia, da condição física, com a prática da virtude. Aponta para a substituição do vício pela virtude, em razão da efemeridade da vida e da juventude, face aos valores perenes que enriquecem e fortalecem o homem.

\footnotetext{
${ }^{1}$ De Anima II, c. 7, q. 8, a.1, 190.

2 Séneca, Questions, I-XVII.4,5, ed. 48-49.
} 
Quando é referido que a natureza nada faz em vão, não se pretende reduzi-la ao aspeto, diríamos, mecânico, fisiológico, onde subsiste uma dependência mais ou menos harmónica dos elementos que compõem fisicamente o homem. Quando se afirma que a natureza nada faz em vão, quer-se apontar para os fins últimos das ações humanas. A natureza, leia-se aqui, a obra de Deus, não faz nada em vão, tudo está ordenado, tudo tem um fim relacionado com o caminho da salvação. Conhecer a natureza é desvendar Deus, e a visão é o sentido mais apropriado para a ciência. ${ }^{102}$

À guisa de conclusão deste $\S$ referiremos que a presença estóica está patente na teoria da visão conimbricense. De uma forma implícita, por tradição, via Galeno, integrando um acervo teórico que principiou na Antiguidade e que foi sucessivamente utilizado e enriquecido vestindo, por vezes, a roupagem de outras doutrinas, mas que foi sempre dotado de elementos caracterizadores próprios, como no caso da descrição do fenómeno da visão desencadeado pelos espíritos visuais junto do ar adjacente e o papel do meio iluminado. Esta posição tornou-se especialmente produtiva graças à possibilidade de conciliação e complementação com a doutrina aristotélica sobre a mesma matéria.

Mas o estoicismo também é chamado à colação de forma explícita quando é convocado a integrar argumentos cuja disputa confronta várias teorias, como no caso dos vedores ou até na forma como a visão ocorre, como vimos supra.

Mas é na discussão sobre os fins últimos da visão que a autoridade de Séneca é claramente assumida e invocada por Góis para sustentar a opinião que afirma que a visão da própria imagem tem como finalidade o aperfeiçoamento moral, favorecer o conhecimento de si e, em última instância, contribuir para a própria salvação mediante a prática da virtude. Cremos que é desta última forma que o estoicismo de Séneca é acolhido por Manuel de Góis. Se não partilhando integralmente o universo da filosofia estóica, pelo menos perfilhando o melhor que dela podia ser retirado e usado para defender a doutrina conimbricense, designadamente, o seu propósito de transformar o ato de ver num ato de pensar a própria conduta, do homem se pensar e conhecer melhor. Aliás, na esteira do que é referido no Proémio deste mesmo Comentário ao 'De anima' quando refere que a ciência da alma tem como escopo principal que o homem se conheça a si mesmo: “... cada um deve, acima de tudo, procurar conhecer-se a si mesmo (...) ninguém se pode conhecer, a menos que tenha examinado atentamente a dignidade e a natureza da sua alma." 103

$\S 4$. Temos sobradas razões para crer que o CAJC, sobretudo o livro da Ética, dialoga criticamente com o neoestoicismo moral ${ }^{104}$. É certo que o en-

102 De Anima II, c.7, q. 6, a.1, 184.

103 De Anima, Prooemium, 1 (trad. port. 179).

104 M.S. de Carvalho, « Des passions vertueuses ? Sur la réception de la doctrine thomiste des passions à la veille de l'anthropologie moderne» in J.F. Meirinhos (ed.), Iti- 
sino formal da ética filosófica não estava disseminado nos colégios jesuítas, os quais deixavam antes para a teologia o tratamento do assunto. Apesar de tudo, isso não sucede completamente em Coimbra que leciona a matéria aristotélica sob o viés mais sistemático e teológico de $\mathrm{S}$. Tomás de Aquino. A ciência moral (scientia moralis) ou filosofia moral considera principalmente as ações humanas, o que com elas se relaciona, e em que consiste a felicida$\mathrm{de}^{105}$, i.e. com a reta norma da vida ${ }^{106}$ que torna a vida perfeita ${ }^{107}$.

Dado que em $\S$ anterior se insistiu numa eventual marca estóica, mormente de Séneca, sobre um dos núcleos da moral do CAJC, concentremo-nos, agora, num aspeto menos positivo. Na verdade, a partir de Lactâncio, de Séneca, e novamente de Cícero e de Galeno, os jesuítas transmitem a opinião dos estóicos, segundo a qual os sábios não se podem entregar às paixões (passiones), a fim de chamar a si a atitude crítica que o Cristianismo impunha. Embora citem a este propósito Cícero (de finibus) é todavia a Cidade de Deus IX a principal fonte nesta crítica. Lembremos de passagem que o século XVI não é só o século de Aristóteles e de Galeno, ele é também o século de S. Agostinho. Se os estóicos, opondo radicalmente a doença (morbus) à sabedoria (sapientia), argumentavam que as perturbações eram indignas para o sábio, contanto que se tratava de comentar Aristóteles, seria imperioso reconhecer-se como semelhante tese estóica poderia ter recebido a oposição de platónicos e de

néraires de la Raison. Études de philosophie médiévale offertes à Maria Cândida Pacheco (Louvain-la-Neuve: FIDEM 2005) 379-403; Manuel de Góis, S.J. Tratado da Felicidade. Introdução e Estudo Complementar de Mário Santiago de Carvalho; nova tradução do original latino por Filipa Medeiros (Lisboa: Edições Sílabo 2009); Id., "Psicofisiologia e teologia das paixões: breve contributo para o tema da (des-)valorização das paixões no século XVI tomista", in G. Burlando (ed.), De las pasiones en la filosofía medieval. Atas del X Congreso Latinoamericano de Filosofia Medieval (Santiago de Chile: Pontificia Universidad Católica de Chile 2009) 391-402; Id., "'Amantes amentes' O papel da memória na antropologia das paixões, segundo o Curso Jesuíta Conimbricense» Cauriensia 7 (2012), 121-139, também em: «'Amantes amentes' O papel da memória na antropologia das paixões, segundo o Curso Jesuíta Conimbricense», in Manuel Lázaro Pulido, José Luis Fuertes Herreros, Ángel Poncela González (Eds.), La Filosofía de las Pasiones y la Escuela de Salamanca Edad Media y Moderna (Cáceres: Instituto Teológico "San Pedro de Alcántara" de Cáceres. Servicio de Publicaciones. Diócesis de Coria-Cáceres 2013), 119-137; de maneira mais ampla: «Metamorfoses da ética peripatética: estudo de um caso Quinhentista conimbricense: 'As Disputas sobre os Livros da Ética a Nicómaco'» Revista Filosófica de Coimbra 14 (2005) 239-274, depois em: Psicologia e Ética no Curso Jesuita Conimbricense (Lisboa: Edições Colibri 2010) 107-39.

105 In libros Ethicorum Aristotelis ad Nicomachum, aliquot Conimbricensis Cursus Disputationes in quibus praecipua quaedam Ethicae disciplinae capita continentur d. 4, prooemium (Lisboa 1593) 31.

106 Physica, Prooemium, q. 3, a. 2, 27.

107 Physica II, c. 6, exp. 253. 
aristotélicos, eles que, afinal, reconheciam a impossibilidade de qualquer sábio se afastar totalmente (omnino) das paixões. Mas, se os demais filósofos haviam chamado paixões aos movimentos do apetite sensitivo, enquanto os estóicos só atendiam aos movimentos perturbadores (turbulentas) do apetite que saem dos limites da razão e da alma (extra limites rationis animumque) e que conduzem aos vícios (ad vitia inflectunt passiones) ${ }^{108}$, a partir da tese filosófica comum, não estóica, podia-se avançar com uma crítica mais ou menos filosófica, em sentido estrito, entendamo-nos.

Como deixámos dito, é pois a partir da Cidade de Deus de S. Agostinho que o CAJC aborda as três eupatheias (constantiae na terminologia ciceroniana), a saber: a vontade em lugar do desejo, o gozo (gaudium) em lugar da alegria (laetitia) e a precaução (cautio) em lugar do temor (metus) ${ }^{109}$. Mas já talvez seja a partir das Tusculanas de Cícero - o volume do De Anima acolhera as definições que Cícero deu das paixões da alma ${ }^{110}$ - e do De Placitis Platonis et Hippocratis, que se rejeita a tese de Crisipo que lia as paixões (perturbationes) como sinais (indicia), opiniões ${ }^{111}$ (opiniones), doenças mesmo ${ }^{112}$. É bem verdade que se tenta salvar a tese de Crisipo, no sentido em que ele não terá interpretado as perturbationes numa aceção formal, mas causal - exemplificando: o medo seria causado pela opinião ou apreensão do mal ${ }^{113}$-, mas tal não impede que v.g. não se veja como a tristeza (aegritudo) e a dor (dolor) não podem dar-se, segundo os estóicos, pois nenhum mal pode acontecer à alma do homem sábio, i. e. daquele cuja vontade apetece o bem, e usa da precaução para evitar o mal.

Infelizmente, na nossa opinião, os jesuítas não colhem, na oportunidade de fazerem a crítica ao neoestoicismo moral, o essencial de um ponto de vista cristão, antes se atendo em demasia a uma posição aristotélica. Comecemos por aqui. Principiando por admitir, naturalmente, que as paixões se encontram nos verdadeiros sábios e naqueles que deveras se ornamentam de virtudes, o elogio feito é à moderação e ao meio-termo (moderationem et mediocritatem). Isentando qualquer mal moral de uma mera consideração das paixões em si mesmas (secundum se), ou seja, como um certo movimento irracional do apetite - note-se que as principais paixões, alegria, tristeza,

108 Ethica d. 6, q. 4, a. 1, 55-6.

109 S. Agostinho, Civ. Dei XIV c. 8 (trad. 1255)

110 De Anima III, c. 13, q. 1, a. 4. 419; definição de Cícero (IV 6, 13, p. 61: "sine ratione animi elationem"; e a de Zenão assim (IV 21, 47, p.77-8): “... perturbatio sit auersa a ratione contra naturam animi commotio, uel breuius, ut perturbatio sit adpetitus uehementior, uehementior autem intellegatur is qui procul absit a naturae constantia" (Cicéron, Tusculanes. Tome II. Texte établi par G. Fohlen et traduit par J. Humbert, Paris 1931).

111 Ethica d. 6, q. 3, a. 2, 55.

112 Ethica d. 6, q. 4, a. 2, 57.

113 Ethica d. 6, q. 3, a. 2, 55; cf. SVF II, 235-63. 
esperança e temor ${ }^{114}$, não pertencem, propriamente, ao apetite racional ${ }^{115}$-, a sua avaliação moral só podia cair necessariamente para o lado da razão e da vontade, único nível em que se pode falar, então, do mal e do bem morais, e assim admitir legitimamente a presença das principais paixões na alma dos sábios ${ }^{116}$. Daí que, a três objeções formuladas de modo preciso - as paixões induzem ao pecado (Rm. 7), são vícios ou doenças da alma, e não está no nosso poder alterá-las quando cedemos ao vício - responde-se com uma versão ou aplicação da doutrina da metriopatheia, a que noutro lugar me referi já, a saber, e respetivamente: se as paixões forem ordenadas pela razão elas são virtudes, só são doenças caso se afastem da regra da moderação, e nunca caímos nelas pelo consentimento (quoad consensum), sempre que a vontade se lhes opõe, mas apenas quanto às mudanças físicas (corporis transmutationem) como v.g. no riso, ou nas lágrimas ${ }^{117}$. É seguro que os jesuítas reconhecem ser uma afirmação comum da filosofia, além de um ensinamento da experiência, que os vícios (vitia) escurecem a mente com a cegueira e as trevas constituindo um verdadeiro impedimento para a luz da verdade ${ }^{118}$, contudo, embora admitindo que elas possuem um duplo caráter, de corrupção e de aperfeiçoamento, afirmam que, no intelecto, as paixões têm um exclusivo papel aperfeiçoador ${ }^{119}$. Comuns à alma e ao corpo ${ }^{120}$, originadas no coração, tal significa que as paixões, também chamadas perturbações da alma (perturbationes animi), podem prejudicar o corpo se forem excessivas e imoderadas ${ }^{121}$, mas podem fazer bem à alma, ao ser humano que se define pela razão e pela vontade. Recordemos que já S. Tomás havia criticado os estóicos neste ponto precisamente por eles não haverem distinguido sentido e entendimento e também apetite intelectivo e sensitivo ${ }^{122}$. Por isso mesmo, e de novo contra o estoicismo, elas vão ser consideradas imprescindíveis para a explicação cabal das virtudes ${ }^{123}$.

114 Ethica d. 6, q. 5, a. 1, 57-58; podem encontrar-se mais paixões, divididas entre a potência concupiscível e a irascível, a saber: amor, desejo, prazer, ódio, fuga, audácia e ira (Ethica d. 6, q. 5, a. 2, 58).

115 Ethica d. 6, q. 5, a. 1, 57.

116 Ethica d. 6, q. 5, a. 1, 57.

117 Ethica d. 6, q. 4, a. 2, 56-7.

118 Physica, Prooemium, q. 5, a. 2, 39.

119 De Anima III, c. 4, exp. 316-17.

120 De Anima I, c. 1, exp.15.

${ }^{121}$ In librum de Vita et Morte c. 6, in Commentarii Collegii Conimbricensis Societatis Iesu In libros Aristotelis, qui Parva Naturalia appellantur (Lisboa 1593) 88; as paixões podem ter a aceção de perturbações ou doenças da alma, sendo a sua causa responsável (causae disponenti et provocanti) atribuída à qualidade das temperaturas do corpo, como, e.g., a melancolia à frieza (frigiditas) (De Anima II, c. 1, q. 1, a. 7, 45).

122 T. de Aquino, Su. theol. I-II, q. 24, a. 2, resp.

123 Ethica d. 6, prooemium, 47. 
Todavia, uma leitura cristã da consciência original, ela que instiga ao bem, deplora o mal sussurrando para que a vontade não viole as normas plenas de verdade e imutáveis, e continuamente avisando os que as violam ${ }^{124}$, deveria ter o seu modelo principal na experiência das paixões em Cristo. Ora, neste particular, a única admissão é a de que o próprio Cristo experimentou o espanto, admiratio ${ }^{125}$, i.e., a paixão da filosofia, precisamente aquela que virá a ser "a primeira de todas as paixões" segundo Descartes ${ }^{126}$. Um manuscrito anónimo de Coimbra com um Comentário ao tratado das paixões de T. de Aquino registado por Stegmüller, elucida-nos sobre o tópico, De passionibus, prout in Christo Domino inveniuntur et in beatis ${ }^{127}$, que nos permite reconhecer também em Portugal a presença do velho motivo augustinista que Jill Kraye identificou em autores imediatamente anteriores ao século dos Jesuítas como em Coluccio Salutati (1331-1406), alegadamente o primeiro a posicionar Cristo perante o estoicismo e a considerar a apatia como incompatível com Ele, e também em Josse Clichtove (1472-1543), em $\mathrm{Ph}$. Melanchton (1479-1560), em Pietro Verrmigli (1499-1562), e finalmente em João Calvino (1509-1564) ${ }^{128}$. Ora, causa alguma perplexidade o facto de os jesuítas conhecerem e citarem o texto de S. Agostinho de crítica à apátheia ou impassibilitas (no seu latim) nesta vida ${ }^{129}$, e não terem reparado que não só Paulo vituperava os seres desprovidos de afetos, como sobretudo, o próprio Cristo, isento de vício embora, tomou a forma de escravo, sentiu tristeza, chorou antes de ressuscitar Lázaro, ou seja, "quis experimentar estas emoções na sua alma humana tal qual como se quis tornar homem"130. É por tudo isto que, como dissemos noutra ocasião, mas neste lugar se torna marginal repetir e desenvolver, somos daqueles que consideram que o CAJC não representa uma significativa contribuição para a revalorização das paixões no Ocidente moderno ${ }^{131}$.

124 De Anima III, c. 8, q. 2, a. 2, 375.

125 De Anima III, c. 13, q. 1, a. 5, 420.

126 R. Descartes, As Paixões da Alma $§ 53$ (sobre a "admiratio"), vd. também $\S 73$ (sobre "stupor") (ed. Descartes, Discuso do Método. As Paixões da Alma, trad. de Newton de Macedo, Lisboa: Sá da Costa 1976, 98 e 105 respetivamente).

127 Cf. F. Stegmüller, Filosofia e Teologia nas Universidades de Coimbra e Évora no século XVI (Coimbra: Universidade de Coimbra 1959), 250, 436.

128 Kraye, "Moral Philosophy" 360-374, 368-69.

129 Cf. S. Agostinho, Civ. Dei XIV c. 9 (trad. 1265).

${ }^{130}$ S. Agostinho, Civ. Dei XIV c. 9 (trad.1264).

131 Cf. Carvalho, "Des passions", 402-3. 
